J. Dairy Sci. 100:8632-8632

https://doi.org/10.3168/jds.2017-100-10-8632

(c) American Dairy Science Association ${ }^{\circledR}, 2017$.

\title{
Corrigendum to "Short communication: Survival of Vaccinia virus in inoculated cheeses during 60-day ripening" (J. Dairy Sci. 100:7051-7054)
}

Izabelle S. Rehfeld, Ana Luiza S. Fraiha, Ana Carolina D. Matos, Maria Isabel M. C. Guedes, Erica A. Costa, Marcelo R. de Souza, Luigi F. L. Cavalcante, and Zélia I. P. Lobato

The name of the seventh author on this paper was misspelled. The correct spelling is Luigi F. L. Cavalcanti.

The authors regret the error.

\section{REFERENCES}

Rehfeld, I. S., A. L. S. Fraiha, A. C. D. Matos, M. I. M. C. Guedes, E. A. Costa, M. R. de Souza, L. F. L. Cavalcante, and Z. I. P. Lobato. 2017. Short communication: Survival of Vaccinia virus in inoculated cheeses during 60-day ripening. J. Dairy Sci. 100(9):7051-7054. https://doi. org/10.3168/jds.2016-12560. 